Dep. of Bacteriology,

Animal Health Research Institute, Mansoura Laboratory.

\title{
SOME BACTERIOLOGICAL, HEMATOLOGICAL AND BIOCHEMICAL CHANGES ON CLINICAL MASTITIS IN GOAT
}

(With 8 Tables and One Figure)

\section{By}

\section{M.M. ABD EL-LATIF; A.H. MOUSTAFA and R.A. EL-RAMADY*}

* Biochemistry, Animal Health Research Institute, Mansoura Laboratory

(Received at 27/1/2010)

بعض الدراسات البكتيريولوجية والدموية والبيوكيميائية علي حالات التهاب الضرع في الماعز والهمو واليز

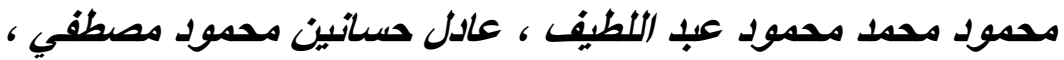
رأفت أحد الرمادي ، عادر هائ

شمل البحث الفحص الإكلينيكي لعدد 120 ماعز مرباة في المزارع الخهار الخاصة بمحافظة الدقهلية

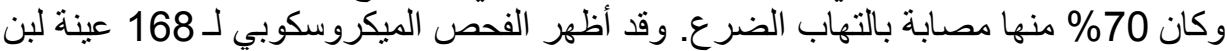

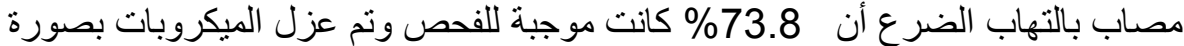

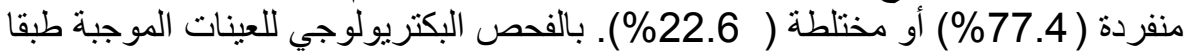

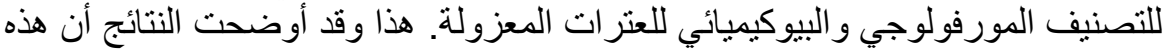

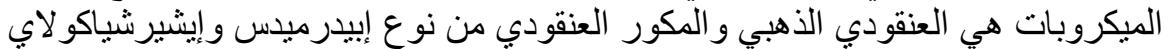

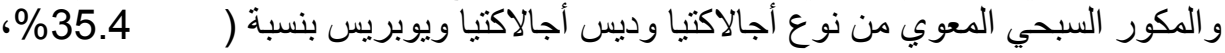

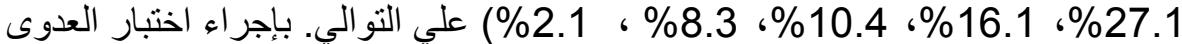

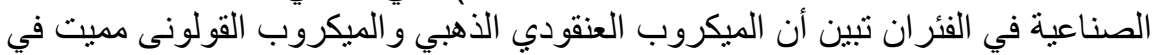

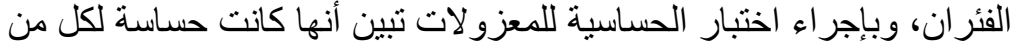

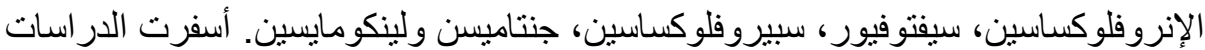

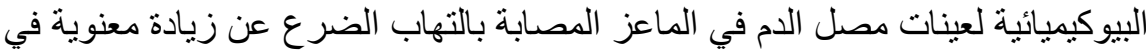

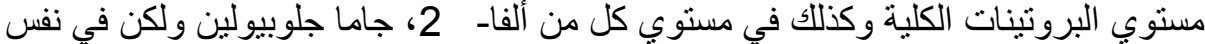

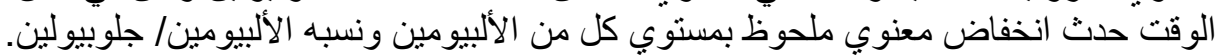

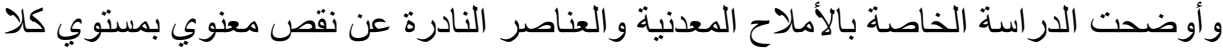

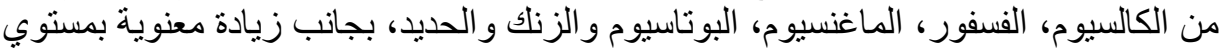

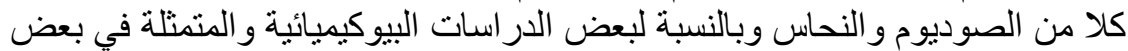
وظائف الكبد و الكلية فقط أوضحت النتائج عن زيادة معنوية في الني مستوي إنزيمات الكبات الكبد ومعدل

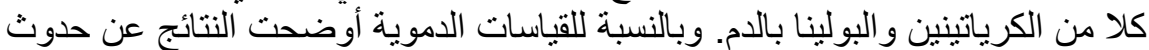
انخفاض معنوي في نسبه الهيموجلوبين بالين و عدد كريات الدم الحمر اء و أيضا العد التصنيات التصنيفى لكلا 


\section{من خلايا الليمفوسايت و النيتروفيل بالاد وفي نفس الوقت حدثت زيادة معنوية بمستوي خلايا المونوسايت، الأزينوفيل و البيزوفيل.}

\section{SUMMARY}

This study included clinical examination of 120 goats bred in different localities of Dakahlia Governorate where $70 \%$ were clinically mastitic. The results of microscopical examination of 168 mastitic milk samples revealed that $73.8 \%$ were positive, $77.4 \%$ out of them gave pure single cultures and $22.6 \%$ yielded mixed ones. The bacteriological examination of positive samples yielded 124 isolates where Staphylococcus aureus, Staph. epidermidis, E. coli, Streptococcus agalactiae, Strept. dysglactiae and Strept. uberis were the main organisms. These strains were isolated at varying percentages $35.4 \%, 27.1 \%, 16.1 \%, 10.4 \%, 8.3 \%$ and $2.1 \%$ respectively. Pathogenicity test in mice revealed that Staph. aureus and $E$. coli were highly virulent strains. The results of the invitro antimicrobial sensitivity test showed that Enrofloxacin, Ceftiofur, Ciprofloxacin, Gentamycin and Lincomycin were the most effective antibiotics for successful treatment of mastitic goats. Biochemical studies of blood serum samples of mastitic does were discussed in details and revealed on increase in the levels of total protein, Alpha 2, gamma globulin, but the level of albumin and A/G ratio were decreased significantly in their values. Meanwhile studies of minerals profiles revealed that, the mean values of $\mathrm{Ca}, \mathrm{IP}, \mathrm{Mg}, \mathrm{K}, \mathrm{Zn}$ and $\mathrm{Fe}$ were decreased significantly, at the same time the level of $\mathrm{Na}$ and $\mathrm{Cu}$ values were increased significantly. Some biochemical liver and kidney functions in the present studies were discussed and revealed a significant increased in the liver enzymes AST, ALT and also in the level of blood urea nitrogen and serum creatinine. Hematological parameters of blood samples of mastitis does were also discussed in details and the studies revealed that, the mean values of $\mathrm{Hb}$, TRBCs, TWBCs were decreased significantly. At the same time, the differential leucocytic count profiles revealed that the percentage of lymphocytes, neutropbils were decreased significantly, while the percentage of monocytes, eosinophils and basophiles were significantly increased.

Key words: Goats, mastitis, udder, milk, blood, antibiogram.

\section{INTRODUCTION}

Mastitis is still the main problem of dairy farms especially when hygienic measures and milking sanitation are often insufficient and 
affecting the quality and quantity of milk, with growth retardation of kids and pre-weaning mortalities (Kennedy and Miller, 1993).

Caprine mastitis is considered to be the result of infection of the mammary glands by specific microorganisms and also malsanitary conditions of the environment (Costa et al., 1998). Clinical caprine mastitis is a serious inflammatory disease manifested by swelling and pain of the udder and very frequently with serious general symptoms (Masisi and Rupinen, 1991). Bacteriological examination of mastitic dairy goats was done by many authors as Topolko and Benic (1997) and Contreras et al. (1999). The most important isolated bacteria are staphylococci, streptococci and E. coli (Raid, 2004; Erson et al., 2005).

Mastitis can be detected by different methods, but an accurate detection could be done mainly by microbiological examination (Brown et al., 1990; Hernandez et al., 1991).

This study was planned to investigate the prevalence of clinical mastitis in goats in addition isolation and biochemical identification of the causative pathogens were considered and antibiogram for the isolated bacterial pathogen was done. Also the study was prompted by findings of hematological and blood serum biochemical changes for detection and diagnosis of mastitic goats.

\section{MATERIALS and METHODS}

\section{Milk Samples:}

A total of 120 she goat collected from a private farm in Dakahlia Governorate and subjected to clinical examination by visual inspection ,palpation of the udder for swelling, redness and pain, beside the physical changes in the milk secreted from such udders with strict aseptic precautions and after discarding the fore milk. Two milk samples from each affected quarter were collected in sterile McCartney bottles and transported to laboratory in ice container for bacteriological examination.

\section{Blood samples:}

Two blood samples were collected from each animals. The first sample was collected from the jugular vein in dry sterilized centrifuge tubes without anticoagulant from goats under study, and allowed to clot at room temperature, then centrifuged to separate serum. The collected sera were kept at $-20^{\circ} \mathrm{C}$ till used for estimation of biochemical parameters. The second blood sample was collected in heparinized tubes for haematological picture.

\section{Bacteriological examination:}


Isolation of bacteria was carried out according to Quinn et al. (1994). Milk samples were incubated aerobically at $37^{\circ} \mathrm{C}$ for $24 \mathrm{hr}$., and then centrifuged at 3000 r.p.m. for 20 minutes. The cream and supernatant fluid were discarded. A loopfull from the sediment was streaked onto the surface of Nutrient agar, MacConkey's agar, Blood agar, EMB and Mannitol salt agar. The inoculated plates were incubated at $37^{\circ} \mathrm{C}$ for $24-48 \mathrm{hr}$. and examined for bacterial growth. The developed colonies were picked up and subcultured for purification. The pure colonies were morphologically identified by Gram-stain and biochemical test (Carter and Cole 1990; Quinn et al., 1994).

Further studies on pure isolates of staphylococci were done. Coagulase activity to different types of plasma (Rabbit, sheep, horse and human) using slide coagulase test were done and confirmed by tube coagulase test.

\section{Pathogenicity:}

Pathogenicity of the recovered bacterial isolates in mice was carried out according to Koneman et al. (1996) and Qunin et al. (2002). 30 white mice were used to investigate the pathogenicity of isolated strains. All mice were examined bacteriological to ensure their freedom from pathogens and were divided into 6 groups, each contained 5 mice injected I/P with $0.5 \mathrm{ml}$. of $5 \times 10^{8}$ C.F.U/ ml. The injected mice were kept under observation for 7 days and the results of mortality and resolution were recorded according to Calvinho and Dodd (1994).

\section{Antibiogram activity:}

Antibiogram of the recovered bacterial isolates: this was done by using disc diffusion standard technique according to Finegold and Martin (1982) and Qunin et al. (2002) using the discs according to Oxoid (1996) of Enrofloxacin, Ciprofloxacin, Ceftiofur, Gentamycin, Lincomycin, Amoxicillin, Trimethoprim-sulfamethoxazole, Oxytetracycline, Streptomycin and Erythromycin.

\section{Biochemical analysis:}

1- Blood serum total proteins were determined according to Sonnenwirth and Jaret, (1980)

2- Albumin was measured spectrophotometrically as described by Drupt (1974). Globulins were calculated mathermatically by substracting the value of albumin from total proteins.

3- Electrophoretic analysis: Electrophoresis of serum samples were determined according to Lewis (1976).

4- Blood serum samples were used also for determination of transaminase enzymes AST, ALT, blood urea, serum creatinine, calcium, phosphorus and magnesium were determined 
spectrophotometrically using standardized test- kits supplied from Bio-Merieux (Baines, France) according to the methods mentioned by McMurray et al. (1984).

Blood serum sodium and potassium were determined using flam photometer (Concerning model AVL 988-3, made in USA) according to method described by Hawk (1965).

Blood serum cupper, iron and zinc were determined using atomic absorption spectrophotometer according to Meret and Henkin, (1971).

The second blood samples were collected in heratinized tube for determination of erythrocytes, total and differential leucocytic counts, haemoglobin concentration according to the standared methods of haematology previously described by Coles (1986).

\section{Statistical analysis:}

The obtained data was simultaneously analyzed statistically using Student test according to Petrie and Wastson (1999).

\section{RESULTS}

Table 1: Prevalence of bacteria causing clinical mastitis among goats.

\begin{tabular}{|c|c|c|c|c|c|}
\hline $\begin{array}{c}\text { Number of } \\
\text { examined } \\
\text { goats }\end{array}$ & $\begin{array}{c}\text { Number of } \\
\text { mastitic } \\
\text { goats }\end{array}$ & $\%^{*}$ & $\begin{array}{c}\text { Number of } \\
\text { quarters of } \\
\text { positive goats }\end{array}$ & $\begin{array}{c}\text { Number of } \\
\text { positive } \\
\text { quarters }\end{array}$ & $\%^{* *}$ \\
\hline 120 & 84 & 70 & 168 & 124 & 73.8 \\
\hline
\end{tabular}

*Percent was calculated according to total number of examined goats.

**Percent was calculated according to number of quarters of positive goats.

Table 2: Prevalence of isolated single and mixed strains in examined milk samples from mastitic goats

\begin{tabular}{|l|c|c|l|c|c|}
\hline \multicolumn{3}{|c|}{ Single isolated bacteria (96) } & \multicolumn{3}{c|}{ Mixed isolated bacteria (28) } \\
\hline \multicolumn{1}{|c|}{ Bacterial strains } & No. & $\%$ & \multicolumn{1}{|c|}{ Bacterial strains } & No. & $\%$ \\
\hline S. aureus & 34 & 35.4 & E. coli + S. aureus & 10 & 35.7 \\
S. epidermidis & 26 & 27.1 & E. coli + S. epidermidis & 5 & 17.9 \\
E. coli & 16 & 16.7 & E. coli + St. agalactiae & 7 & 25.0 \\
St. agalactiae & 10 & 10.4 & E. coli + St. & 4 & 14.3 \\
St. dysgalactiae & 8 & 8.3 & dysgalactiae & & 7.1 \\
St. uberis & 2 & 2.1 & E. coli + St. uberis & 2 & \\
\hline \multicolumn{1}{|c|}{ Total } & 96 & 77.4 & & 28 & 22.6 \\
\hline
\end{tabular}

* Percent was calculated according to total number of isolated bacteria of each. 
Assiut Vet. Med. J. Vol. 56 No. 125 April 2010

Table 3: Pathogenicity of bacteria isolated from clinical mastitic goats

\begin{tabular}{|c|c|c|c|c|c|c|c|c|c|}
\hline \multirow{2}{*}{ Bacteria isolates } & \multicolumn{7}{|c|}{ No of dead mice/ day } & \multicolumn{2}{|c|}{ Total } \\
\hline & 1 & 2 & 3 & 4 & 5 & 6 & 7 & No & $\%$ \\
\hline S. aureus & 0 & 1 & 1 & 1 & 0 & 1 & 1 & $4 / 5$ & 80 \\
\hline E. coli & 0 & 0 & 1 & 1 & 0 & 1 & 0 & $3 / 5$ & 60 \\
\hline S. epidermidis & 0 & 0 & 1 & 1 & 0 & 0 & 0 & $2 / 5$ & 40 \\
\hline St. agalactiae & 0 & 0 & 0 & 1 & 1 & 0 & 0 & $2 / 5$ & 40 \\
\hline St. dysaglactiae & 0 & 0 & 0 & 1 & 0 & 1 & 0 & $2 / 5$ & 40 \\
\hline St. uberis & 0 & 0 & 0 & 1 & 0 & 0 & 0 & $1 / 5$ & 20 \\
\hline
\end{tabular}

* The percent was calculated according to the total number of mice in each group.

Table 4: Antibiogram of the most isolated microorganism recovered from clinical mastitic goats

\begin{tabular}{|c|c|c|c|c|c|c|c|c|c|c|c|c|}
\hline \multirow[b]{2}{*}{$\begin{array}{l}\text { Antibacterial } \\
\text { agent and its } \\
\text { potency }\end{array}$} & \multicolumn{2}{|c|}{$\begin{array}{l}\text { S. aureus } \\
(\mathrm{No}=34)\end{array}$} & \multicolumn{2}{|c|}{$\begin{array}{l}\text { S. epidermidis } \\
(\mathrm{No}=26)\end{array}$} & \multicolumn{2}{|c|}{$\begin{array}{c}\text { E. coli } \\
(\mathrm{No}=16)\end{array}$} & \multicolumn{2}{|c|}{$\begin{array}{l}\text { St. agalactiae } \\
\qquad(\mathrm{No}=10)\end{array}$} & \multicolumn{2}{|c|}{$\begin{array}{c}\text { St. } \\
\text { dysgalactiae } \\
(\mathrm{No}=8)\end{array}$} & \multicolumn{2}{|c|}{$\begin{array}{l}\text { St. uberis } \\
(\mathrm{No}=2)\end{array}$} \\
\hline & $\begin{array}{c}\text { Sensitive } \\
\text { isolates }\end{array}$ & $\%$ & $\begin{array}{c}\text { Sensitive } \\
\text { isolates }\end{array}$ & $\%$ & $\begin{array}{c}\text { Sensitive } \\
\text { isolates }\end{array}$ & $\%$ & $\begin{array}{l}\text { Sensitive } \\
\text { isolates }\end{array}$ & $\%$ & $\begin{array}{l}\text { Sensitive } \\
\text { isolates }\end{array}$ & $\%$ & $\begin{array}{r}\text { Sensitive } \\
\text { isolates }\end{array}$ & $\%$ \\
\hline Enrofloxacin $5 \mu \mathrm{g}$ & 28 & 82.4 & 20 & 76.9 & 14 & 87.5 & 8 & 80 & 7 & 87.5 & 2 & 100 \\
\hline Ciprofloxacin $20 \mu \mathrm{g}$ & 30 & 88.2 & 22 & 84.6 & 11 & 68.8 & 6 & 60 & 5 & 62.5 & 1 & 50 \\
\hline Ceftiofur $\quad 30 \mu \mathrm{g}$ & 31 & 91.2 & 21 & 80.8 & 13 & 81.3 & 7 & 70 & 5 & 62.5 & 2 & 100 \\
\hline Gentamycin $10 \mu \mathrm{g}$ & 25 & 73.5 & 19 & 73.1 & 12 & 75.0 & 6 & 60 & 6 & 75 & 1 & 50 \\
\hline Amoxycillin $25 \mu \mathrm{g}$ & 14 & 41.2 & 11 & 42.3 & 8 & 50.0 & 4 & 40 & 0 & 0.0 & 0 & 0.0 \\
\hline Lincomycin $15 \mu \mathrm{g}$ & 24 & 70.6 & 18 & 69.2 & 13 & 81.3 & 7 & 70 & 6 & 75 & 1 & 50 \\
\hline $\begin{array}{l}\text { Trimethoprim- } \\
\text { sulpamethoxazol } \\
25 \mu \mathrm{g}+23.75 \mu \mathrm{g}\end{array}$ & 0 & 0.0 & 0 & 0.0 & 10 & 62.5 & 5 & 50 & 4 & 50 & 0 & 0.0 \\
\hline Oxytetracycline $30 \mu \mathrm{g}$ & 18 & 52.9 & 16 & 61.5 & 8 & 50.0 & 5 & 50 & 5 & 62.5 & 1 & 50 \\
\hline Streptomycin $10 \mu \mathrm{g}$ & 16 & 47.1 & 14 & 53.8 & 11 & 68.8 & 4 & 40 & 4 & 50 & 0 & 0.0 \\
\hline Erythromycin $10 \mu \mathrm{g}$ & 12 & 35.3 & 12 & 46.2 & 8 & 50.0 & 5 & 50 & 3 & 37.5 & 1 & 50 \\
\hline
\end{tabular}

No $=$ Number of isolates. 
Table 5: Mean values of total serum protein and electrophoretic pattern $(\mathrm{gm} / \mathrm{dl})$ of control healthy and mastitic goats

\begin{tabular}{|c|c|c|}
\hline Parameter $\quad$ Unit & Control group & Mastitic group \\
\hline Total protein $(\mathrm{gm} / \mathrm{dl})$ & $6.15 \pm 0.51$ & $8.92 \pm 0.60^{* *}$ \\
\hline Albumin $\quad(\mathrm{gm} / \mathrm{dl})$ & $2.04 \pm 0.13$ & $1.55 \pm 0.14^{*}$ \\
\hline$\alpha 1-$ globulin $(\mathrm{gm} / \mathrm{dl})$ & $1.35 \pm 0.09$ & $1.48 \pm 0.11$ \\
\hline a2-globulin $\quad(\mathrm{gm} / \mathrm{dl})$ & $0.52 \pm 0.09$ & $1.34 \pm 0.12^{* *}$ \\
\hline$\beta$-globulin $\quad(\mathrm{gm} / \mathrm{dl})$ & $1.20 \pm 0.12$ & $1.29 \pm 0.18$ \\
\hline$\gamma$-globulin $\quad(\mathrm{gm} / \mathrm{dl})$ & $1.04 \pm 0.09$ & $3.26 \pm 0.25^{* *}$ \\
\hline Total globulin (gm/dl) & $4.11 \pm 0.29$ & $7.37 \pm 0.47^{* *}$ \\
\hline $\mathrm{A} / \mathrm{G}$ ratio & $0.50 \pm 0.04$ & $0.21 \pm 0.025^{* *}$ \\
\hline
\end{tabular}

*Signifiant at $\mathrm{p}<0.05$

$* *$ Signifiant at $\mathrm{p}<0.01$

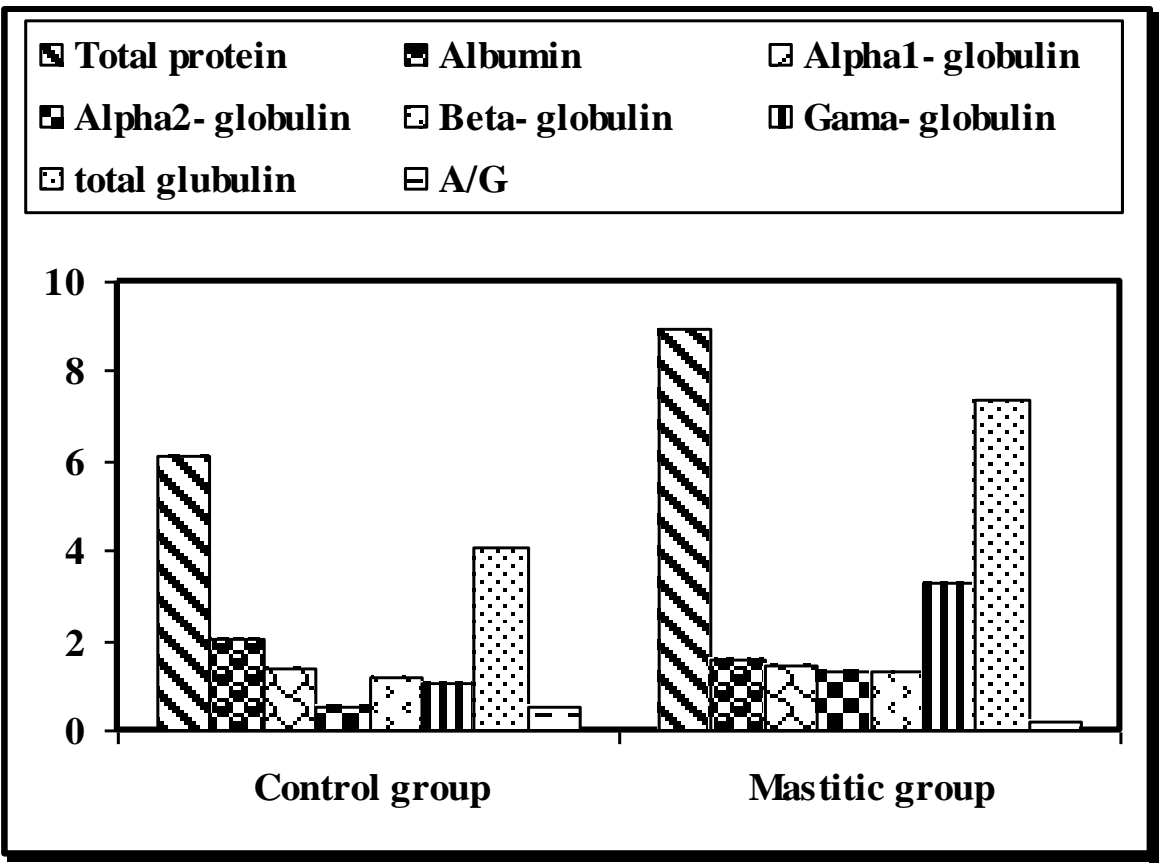

Fig. 1: Mean values of total serum protein and electrophoretic pattern $(\mathrm{gm} / \mathrm{dl})$ of control healthy and mastitic goats 
Table 6: Mean values of minerals in serum of control healthy and mastitic goats

\begin{tabular}{|lc|c|c|}
\hline Parameters & Unit & Control group & Mastitic group \\
\hline $\mathrm{Ca}$ & $(\mathrm{mg} \%)$ & $11.6 \pm 0.28$ & $8.5 \pm 0.30^{*}$ \\
$\mathrm{IP}$ & $(\mathrm{mg} \%)$ & $5.8 \pm 0.18$ & $5.1 \pm 0.20^{*}$ \\
$\mathrm{Mg}$ & $(\mathrm{mg} \%)$ & $2.6 \pm 0.16$ & $1.46 \pm 0.30^{*}$ \\
$\mathrm{Na}$ & $(\mathrm{mEq} / \mathrm{L})$ & $129 \pm 2.2$ & $140 \pm 3.0^{*}$ \\
$\mathrm{~K}$ & $(\mathrm{mEq} / \mathrm{L})$ & $5.4 \pm 0.93$ & $3.8 \pm 0.020^{*}$ \\
$\mathrm{Cu}$ & $(\mathrm{ug} \%)$ & $60.4 \pm 1.6$ & $81.2 \pm 2.4^{* *}$ \\
$\mathrm{Zn}$ & $(\mathrm{ug} \%)$ & $75.9 \pm 1.65$ & $56.2 \pm 3.1^{* *}$ \\
$\mathrm{Fe}$ & $(\mathrm{ug} \%)$ & $156.7 \pm 4.1$ & $130.4 \pm 3.3^{* *}$ \\
\hline
\end{tabular}

*Significant at $\mathrm{p}<0.05$

** Significant at $\mathrm{p}<0.01$

Table 7: Mean values of some liver and kidney functions in control healthy and mastitic goats

\begin{tabular}{|lc|c|c|}
\hline Parameters & Unit & Control group & Mastitic group \\
\hline AST & $(\mathrm{iu} / \mathrm{L})$ & $40 \pm 1.3$ & $80.0 \pm 3.1^{* * * *}$ \\
ALT & $(\mathrm{iu} / \mathrm{L})$ & $38 \pm 1.5$ & $70.0 \pm 2.9^{* * *}$ \\
Urea & $(\mathrm{mg} \%)$ & $28 \pm 0.9$ & $44.4 \pm 1.8^{* *}$ \\
Creatinine & $(\mathrm{mg} \%)$ & $0.42 \pm 0.03$ & $1.3 \pm 0.08^{* *}$ \\
\hline
\end{tabular}

$* *$ Significant at p. $<0.01$

$* * *$ Significant at $\mathrm{p}<0.001$

Table 8: Mean values of the haemogram of control healthy and mastitic goats

\begin{tabular}{|lr|c|c|}
\hline Parameters & Unit & Control group & Mastitic group \\
\hline $\mathrm{Hb}$ & $(\mathrm{gm} / \mathrm{dl})$ & $9.9 \pm 0.8$ & $8.0 \pm 0.6^{*}$ \\
$\mathrm{RBC}_{\mathrm{S}}$ & $(\mathrm{T} / \mathrm{L})$ & $8.1 \pm 0.6$ & $6.9 \pm 0.4^{*}$ \\
$\mathrm{WBC}_{\mathrm{S}}$ & $(\mathrm{G} / \mathrm{L})$ & $9.2 \pm 0.6$ & $5.1 \pm 0.1^{* *}$ \\
D.L.C \% & & & \\
Lymphocytes & $(\%)$ & $57.0 \pm 2.07$ & $49.4 \pm 1.79^{*}$ \\
Lymphocytes & $(\%)$ & $35.6 \pm 1.09$ & $29.7 \pm 0.91^{*}$ \\
Monocytes & $(\%)$ & $4.6 \pm 0.39$ & $10.8 \pm 0.90^{*}$ \\
Eosinophils & $(\%)$ & $2.5 \pm 0.15$ & $7.9 \pm 046^{*}$ \\
Basophils & $(\%)$ & $0.30 \pm 0.01$ & $2.2 \pm 0.24^{* *}$ \\
\hline
\end{tabular}

*Significant at $\mathrm{p}<0.05$

** Significant at $\mathrm{p}<0.01$
T/L Terra /Liter

G/L Giga /Liter 


\section{DISCUSSION}

Mastitis in goat is a problem that requires excessive studies. This necessitates recognizing the causative agent which is a complex object since many microorganisms were incriminated in the occurance of mastitis in goats which could act alone or may have synergistic effect (El-Shabiny et al., 1996).

The date presented in Table 1 showed that the prevalence of bacteria causing mastitis in goats was $73.8 \%$, from the total examined quarter milk samples (168), in this concern, El-Khodery and Hoedemaker (2005) recorded that the prevalence of bacteria causing mastitis was 69.7\%.Meanwhile Assefa et al. (2006) recorded that the prevalence of bacteria yielded from lactating goats was $89.9 \%$. Bacterial causes of mastitis in goats were also studied by some authors such as Topolko and Benic, (1997) and Machado et al. (1999). The results presented in Table 2 showed the prevalence of bacteria isolated from clinical mastitis in goats, where $S$. aureus, S. epidermidis, E. coli, St. agalactiae, St. dysgalactiae and St. uberis were isolated with different incidences, it was noticed that the highest incidences were for S. aureus (35.4\%), then S. epidermidis $(27.1 \%)$ and E. coli $(16.7 \%)$. Many investigators studied the most prevalence of bacteria isolated from mastitis in goats as Ajuwape et al. (2005) who isolated Staphylococcus epidermidis $(50.9 \%)$ and E. coli $(15.1 \%)$ from mastitic goats. In addition, Moawad and Osman (2005) recovered S. epidemidis $(50 \%)$ and S. aureus $(30.65 \%)$ from dairy ewes. They also isolated St. agalactiae in (9.7\%) and E. coli (4.84\%), otherwise, Mohy and Abdel Fattah (2008) isolated S. aureus (40\%) from 50 random goat milk samples. Meanwhile, Laila et al. (2000) isolated S. aureus, St. agalactiae, St. dysgalactiae, St. uberis and E. coli with a percentage $25 \%, 16.6 \%$, $16.6 \%, 8.3 \%$ and $8.3 \%$ respectively from mastitic goats.

The results presented in Table 2 showed the combination between bacterial isolates that induced mastitis in goats. This combination occurred mainly between $E$. coli $+S$. aureus (10 samples) followed by $E$. coli + St. agalactiae (7 samples), E. coli S. epidermidis ( 5 samples), E. coli + St. dysgalactiae (4 samples) and St. uberis (2 samples). In this concern, Hanaa et al. (2005) reported that $18.7 \%$ of milk samples had mixed infection with $S$. aureus and St. agalaciae.

It was noticed from Table 3 that the virulence of some bacteria isolated from mastitis in goats, as demonstrated by the sequence of mortality in mice. S. aureus and E. coli were virulent strains followed by S. epidermidis, St. agalaciae, St. dysgalactiae and St. uberis. These may 
by attributed to pathogenic nature of the strain or the presence of virulence associated plasmid or production of endo. or exotoxins. These results coincided to some extent with those of Magda, (2007) who reported that $S$. aureus and St. agalactiae were virulent strains followed by E. coli, S. epidermidis, St. dysgalactiae.

Table 4 showed the antibiogram of 10 chemotherapeutic agents on 5 isolates from milk of mastitic goats. Most isolates were sensitive to enrofloxacin, ciprofloxacin, ceftiofur, gentamycin and lincomycin. Mohan et al. (2004) cited that S. aureus, E. coli and Streptococcus spp. were sensitive to Enrofloxacin, Gentamycin, Ciprofloxacin and Chlormphenical. In addition, Sharma et al. (2005) recorded that Staphylococcus spp., Streptococcus spp. and Enterobacteriae spp. were highly sensitive to Ciprofloxacin, Gentamycin, Chlormphenical and Tetracycline.

Concerning total serum protein and its fractions values, our results in Table 5 showed that a significant increase in total protein, $\alpha 2-$ and $\gamma$ globulin and a significant decrease in serum albumin and $\mathrm{A} / \mathrm{G}$ ratio were also detected but $\alpha-1$ and $\beta$ - globulin demonstrated non significant changes in their values in mastitic goat if compared with the healthy ones. Similar results were recorded by Rashed et al. (2002) and Fatma, Darwish et al. (2003) who reported that, a significant drop in blood serum albumin and $\mathrm{A} / \mathrm{G}$ ratio accompanied by significant increase in $\alpha 2, \beta$ and $\gamma$ globulin were detected. Also, Beisel, (1976) noticed that a decrease in blood serum albumin level was detected and also characteristic for chronic inflammatory process.

Also, Pesce and Kaplan, (1987) observed an elevation in blood serum globulins which could be referred to an inflammatory reaction due to chronic infections of mammary tissues. On the contrary, Said, (1968) found that mastitis due to coliform bacteria did not changed serum proteins values from normal range. Our observation came in agreement with most finding reported by Rawdat et al. (1999) who mentioned that total protein and its fractions showed that there was a significant decrease in serum albumin and $\beta$ - globulin. On the other side, observed a significant elevation in alpha and gamma globulins.

Our data concerning the level of minerals in Table 6 revealed that, blood serum calcium, phosphorus, magnesium, potassium, zinc and iron were showed a significant decrease in their values but the concentration of sodium and copper demonstrated a significant increase in their average. Similar findings were pastulated by Beisel, (1976) who mentioned that hypercopremia was associated with hypozincemia and 
due to occuring infections. Roeser (1980) concluded that hypoferraemia is a mechanism that limits bacterial, multiplication by deprivation of $\mathrm{Fe}$, these bacteria have the ability to cause generalized inflammatory changes, although hypoferraemia may limit the spreading of the organism from the gland to different organs. Also potassium level reported significant decrease in mastitic animals but sodium did not revealed any significant difference between healthy and mastitic animals.

As mentioned before in our study concerning calcium, phosphorus and magnesium levels were decreased significantly and these observed results came in agreement with the observation of Sandholm el al. (1995) who reported that, during mastitis the selective ability of the udder epithelium to concentrate ions is weakened and the passive permeability increase. As a consequence, the salts concentration in blood and milk balanced in such a way that sodium become more concentrated and the amount of calcium, phosphorus, magnesium and potassium decreased considerably.

Our results illustrated the variation in values of AST, ALT, area and creatinine in mastitic does when compared with control ones. Table 7 showed that parameters are altered in mastitic does by increasing significantly in their values. But there was no correlation between serum concentration of these parameters and clinical mastitis. This may be attributed to the extent of changes in blood parameters which varied with the severity of mastitis and these results are in accordance with that reported by Bertoni et al. (1994)

Results concerning hematological profile of mastitic goats when compared with control ones were tabulated in Table 8 which revealed a significant statistical depression in total RBCs count (oligocythemia), haemoglobin value; marked leucopenia, total and differential leucocytic count especially lymphocytes, neutrophils percentages with exception of monocytes, eosinophils and basophils percentages which showed a significant increase in their values. Such increase in monocytes indicating the chronicity mean while increasing in esinophils and basophilis percentages reflect the condition of allergx. Our findings came in agreement with the finding of Radostits et al. (1994) who reported that in peracute picture of the disease, the total and differential leucocytic counts are characteristic and useful diagnostic aids, where there are a marked leucopenia, neutropenia and degenerative shift to left. This is due to the migration of large numbers of neutrophils into the affected udder. The extent of changes in different blood parameters was varied with the severity of mastitis. 
In conclusion, high prevalence of environmental bacterial clinical mastitis in goat was mainly caused by Staph. aureus, E. coli and Streptococcus spp. and proved as an under pathogens. Enrofloxacin, Ceftiofur, Ciproflaxacin, Gentamycin and Lincomycin are the drugs of choice which could be successfully used for the treatment of mastitic goats. Obtained hematological and biochemical profiles and their alteration in mastitic goats may not be enough for diagnosis of mastitis in goats, but marked leucopenia and neutropenia were characteristic for diagnostic aid in early stage of clinical mastitis.

\section{REFERENCES}

Ajuwape, A.T.P.; Roberts, A.A.; Solarino, O.O. and Adetosoye, A.I. (2005): Bacteriological and hematological studies of clinical mastitis in goats in Ibadan, OYO State, Nigeria. Small Ruminant Research. 60(3): 307-310.

Assefa Wakwoya; Bayleyegn Molla; Kelay Belihu; Kleer, J. and Hildebrandt, G. (2006): A cross-sectional study on the prevalence, antimicrobial susceptibility patterns and associated bacterial pathogens of goat mastitis. Inter. Journal of Applied Research in Vet. Med. 4 (2): 169-176.

Beisel, W.R. (1976): Trace elements in infectious processes. Med. Clin. North. Am., 60: 831-849.

Bertoni, G.; Terivisi, E.; Capelli, F.P. and Cappa, V. (1994): Variation in blood parameters with mastitis of different severity in dairy cows. Bologna, Italy; Societa Italiana di Buiatria, Z., 1427-1430.

Brown, M.B.; Shearer, K.J. and Elivinger, F. (1990): Mycoplasma mastitis in a dairy herd. J. Am. Vet. Med. Ass., 196: 1097- 1101.

Calvinho, L.E. and Dodd, K. (1994): Virulence for mice of Staphylococcus aureus strains from bovine mastitis related to colonial morphology and serological types in serum soft agar. J. Vet. Med., 41(5): 328-335.

Carter, G.R. and Cole, J.R. (1990): Diagnostic procedures in Vet. Bacteriology and Mycology $5^{\text {th }}$ Ed. Academic Press. Inc., Hore Court Brace Jovanovich Publishers.

Coles, E.H. (1986): Veterinary Clinical. $4^{\text {th }}$ Ed., W.B. Saunders Comp.

Contreras, A.; Paape, M.J. and Miller, R.H. (1999): Prevalence of subclinical intramammary infection caused by Staphylococcus 
epidermis in a commercial diary goat herd. Small Ruminant Res. 31 (3): 203-208.

Costa, E.O.; Riberiro, A.R.; Watanabe, E.T. and Melville, P.A. (1998): Infectious bovine mastitis caused by (environmental) organisms. J. Vet. Med., 45 (2): 65-71.

Drupt, F. (1974): Colorimetric method for determination of albumin. Pharm. Biol., A: 777-779.

El-Khodery, S.A. and Hoedemaker, M. (2005): "Incidence and type of mastitis in the livestock of northern Germany concerning management factors". $4^{\text {th }}$ Int. Conf., Mansoura. 973: 987.

El-Shabiny, L.M.; Seleim, R.S.; Shaker, M.H.; El-Sharnobi, R.; Hafez, M.A.M.; El-Ebeedy, A.A. and Ibrahium, F.A.R. (1996): Mycoplasma arginini and Pasteurella multocida infections as a field problem in goats. Beni-Suef Vet. Med. Res., 6: 181- 200.

Esron, D.K.; Lughano, J.K.; Robinson, H.M.; Angolwisye, M.K; Calvin,

S. and Dominic, M.K. (2005): Studies on mastitis, milk quality and health risks associated with consumption of milk from pastoral herds in Dodoma and Morgoro regions, Tanzania. J. Vet. Sci. 6 (3): 213-221.

Fatma, M.M. Darwish; Aisha, R. Ali and Amany E. Youssef (2003): Immunohistochemical, pathological and biochemical studies on mastitis in sheep and goats Associated with Bacterial Infection. J. Egypt. Vet. Med. Assoc., 63(1): 121-149.

Finegold, S.M. and Martin, W.T. (1982): "Diagnostic Microbiology". $6^{\text {th }}$ Ed. C.V. Mosby CO. St. Louis Toronto, London.

Hanaa, A. Alam; Raghib, R.W.; Mettias, K.N. and Amal, A. El-Rashidy (2005): Application of bulk tank analysis in Egyptian dairy farms. J. Egypt. Vet. Med. Assoc., 65 (1): 237-247.

Hawk, P.B. (1965): Hawk's Physiological Chemistry. $4^{\text {th }}$ Ed. Oser, B.L, McGrow, Hill, Inc. New York.

Hernandez, A.L.; Chavez, A.E.P. and Pereze, D.M. (1991): Antimicrobial sensitivity and B-Lactamase production of Staph. aureus and coagulas negative staphylococci isolated from bovine mastitis. Veterinaria Mexico. 22 (30): 290-294.

Kennedy, P.C. and Miller, R.B. (1993): The female reproductive system. cited in Jubb, K.V.F., Peter, C.K. and Palmer, N. (1993): Pathology of domestic animals, "4 ${ }^{\text {th }}$ Ed., Academic Press, California, USA.

Koneman, E.W.; Allen, S.D.; Janda, W.M.; Schreckenberger, P.C. and Winn, W.C. (1996): Introduction Diagnostic Microbiology. $5^{\text {th }}$ Ed. Lippincott Company, Philadelphia, U.S.A. 
Laila, M. El-Shabiny; Nada, H.S. and Manal Abo El-Makarem (2000): Bacterial mastitis in she goats with special reference to Mycoplasma infection. J. Egypt. Vet. Med. Assoc., 60, (5): 177-186.

Lewis, J.H. (1976): Comparative hematology studies on goats. Am. J. Vet. Res., 37: 601-605.

Machado, M.; Tavares, A. and Neves, D. (1999): Characters of staphylococci isolated in milk from ewes and goats with suspected mastitis. Veterinarian Tecnica, 9. (2): 36-42.

Magda F. Essa (2007): Some studies on bacterial causes of mastitis in buffaloes. J. Egypt. Vet. Med. Assoc. 67 (3): 129-139.

Maisis, P. and Rupinen, J. (1991): Pathogenicity of different species of staphylococci in caprine udder. Br. Vet. J., 147: 126-132.

McMurray, C.H.; Bianchflower, W.J. and Rice, D.A. (1984): A kinetic enzymatic method to measure the level of $\mathrm{D}$ - 3 hydroxybutyrate in serum of plasma. Clin. Chem., 30: 3.

Meret, S. and Henkin, R. (1971): Simultaneous direct estimation of copper and zinc in serum, urine and cerebrospinal fluid. Chem., 175: 189.

Moawad, A.A. and Osman, S.A. (2005): Prevalence and aetiology of subclinical mastitis in dairy ewes at Fayoum Governorate, Egypt. Assiut Vet. Med. J. 51 (107): 135-149.

Mohan, M.M.; Siji, P.C.; Ttresamol, P.V. and Saseendranath, M.R. (2004): Management of clinical mastitis in goats. Indian J. of Vet. Med., 24 (2): 123-124.

Mohy, A.A. Mohsen and Abdel-Fattah, S.A. (2008): Bacteriological study on goat's milk in North Sinai Governorate. V.J. (ISSN.1110- 1458)36(1): 134-138.

Oxoid Manual (1996): Culture media, ingredients and other laboratory services. $15^{\text {th }}$ Ed., Published by Oxoid Ltd., London.

Pesce, J. and Kaplan, L.A. (1987): Clinical Chemistry. p. 85, Eds. Mosby. St. Louis, Washington, USA.

Petrie, A. and Wastson, P. (1999): Statistics for Veterinary and Animal Science. $1^{\text {st }}$ Ed. 90-99. The Black Well Science Ltd., United Kingdom.

Quinn, P.J.; Carter, M.S.; Markyl, B. and Carter, G.R. (1994): Clinical Vet. Microbiology. Mosby- Year Book Europe Limited.

Quinn, P.J.; Markey, B.K.; Carter, M.E.; Doneliy, W.J.C. and Leonard, F.C. (2002): Veterinary Microbiology and Microbial Diseases. $1^{\text {st }}$ Iowa State University Press, Blackwell Science. 
Radosits, O.M.; Blood, D.C. and Gay, C.C. (1994): Bovine Mastitis, Veterinary Medicine, $8^{\text {th }}$, Ed. The Batli press, Avoin, London 563-574.

Rashed, M.A.; Mogada, K.; Masour, K.H. and Korietum, Kh. M. (2002): Biochemical changes in blood and milk of mastitic cows. Egypt. J. Comp. Clinic. Path., 15: 74-83.

Rawdat, A. Metawie and Omaima, M. Mohamed (1999): Some biochemical changes in milk and serum of mastitic Egyptian buffaloes. Zag. Vet. J. (ISSN. 1110- 1458) 27 (2): 38-44.

Riad, E.M. (2004): DNA fingerprinting by polymerase chain reaction for detection of Staphylococcus aureus in mastitic cows. J. Egypt. Vet. Med. Assoc., 64 (2): 229-235.

Roeser, H.P. (1980): Iron metabolism in inflammation and malignant disease, in iron in biochemistry and medicine, $2^{\text {nd }}$ ed., A. Jacobs and Warwood, Eds., Academic Press. London, 605-640.

Said, A.H. (1968): Experimental coliform mastitis in rabbits. Zbl. Vet. Med. Reibe., Bd. 16, Heft, 5, p. 289-403.

Sandholm, M.; Buzalis, T.H.; Heartinen, L. and Pyorala, S. (1995): The bovine udder and mastitis. Gummerus Kirjapaino Oy. Jyvaskyla, Finland.

Sharma, S.K.; Tnwar, R.K. and Gahlot, A.K. (2005): In-vitro antibiotic sensitivity of bacterial isolates from caprine subclinical mastitis. Vet. Practitioner. 6 (2): 129-130.

Sonnenwirth, A. and Jaret, L. (1980): Gardwhols Clinical Laboratory Methods and Diagnosis. "Vol. I. $8^{\text {th }}$ ed., Mosby, Washington.

Topolko, S. and Benic, M. (1997): Problems and epidemiology of subclinical mastitis in small-farm milk production. Praxis Veterinarian, 45: 69-76. 